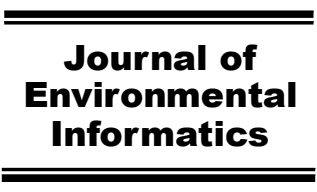

www.iseis.org/jei

\title{
Effects of Early Dry Season on Habitat Suitability for Migratory Birds in China's Two Largest Freshwater Lake Wetlands after the Impoundment of Three Gorges Dam
}

\author{
H. P. Wu ${ }^{1 *}$, J. Chen ${ }^{1}$, G. M. Zeng ${ }^{2,3 *}$, J. J. Xu' ${ }^{1}$, L. H. Sang ${ }^{1}$, Q. Liu ${ }^{1}$, J. Dai ${ }^{1}$, W. P. Xiong ${ }^{2,3}$, Z. Yuan ${ }^{1}$, \\ Y. Q. Wang ${ }^{1}$, and S. J. Ye $\mathrm{e}^{2,3}$ \\ ${ }^{1}$ Changjiang River Scientific Research Institute, Wuhan, 430010, PR China \\ ${ }^{2}$ College of Environmental Science and Engineering, Hunan University, Changsha 410082, PR China \\ ${ }^{3}$ Key Laboratory of Environmental Biology and Pollution Control (Hunan University), Ministry of Education, Changsha 410082, PR China.
}

Received 09 December 2017; revised 19 April 2018; accepted 14 September 2018; published online 22 April 2019

\begin{abstract}
Dongting Lake and Poyang Lake, the China's two largest freshwater lakes, are the most important wintering area and pathways for migratory birds in East Asia. As a result of human activities (impounding of the Three Gorges Dam (TGD), and sand mining) and climate change, the dry season of Dongting Lake and Poyang Lake came early after the impoundment of TGD. And the early dry season (EDS) would change wildlife habitat and would have a negative effect on biology and biodiversity. In this paper, we compared the habitat suitability for Anatidae, Charadriidae, Ardeidae and Laridae (the four main types of migratory birds) of the Dongting Lake and Poyang Lake between three normal hydrologic years (NY) and three hydrologic years which had EDS (EY) of each lake by geo-spatial overlay calculation, to reveal the effect of EDS on the habitat suitability for the main types of migratory birds. The grading systems of suitability included four grades: poor (0-25), fair (25-50), good (50-75), and very good (75-100). The results showed that the EDS 1) improved the habitat suitability for Anatidae; 2) had no significant influence on the habitat suitability for Charadriidae and Ardeidae; and 3) had an almost significant adverse effect (would be significant in fact and in the future) on the habitat suitability for Laridae at the two wetlands.
\end{abstract}

Keywords: early dry season (EDS), Three Gorges Dam, habitat suitability, migratory birds, Dongting Lake, Poyang Lake

\section{Introduction}

Wetlands (rivers, lakes, bogs, etc.) provide habitats for biota and are well-known for their key role in global biodiversity protection (Wu et al., 2015; Dai et al., 2016). Because of human activities (such as damming and water transfer) and climate change, the hydrologic cycles (flood duration, start date of the dry season, etc.) of most large rivers around the world were dramatically changed over the past one hundred years $(\mathrm{Li}-$ gon et al., 1995; Wu et al., 2015; Xie et al., 2018; Xin et al., 2018), and also were expected to be changed over the next one hundred years (Milly et al., 2002; Wu et al., 2017). Changes in the hydrologic cycle would directly impact biota, ecosystem processes and ecosystem services of wetlands (Auble et al., 1994; Wu et al., 2015; Wu et al., 2017; Liu et al., 2018a). It is also particularly true that migratory birds are highly dependent on the amplitude and timing of water level changes (Bancroft et al., 2002; Smith et al., 2003; Zhang et al., 2007).

There are two lakes, Dongting Lake and Poyang Lake, at

*Corresponding author. Tel.: +86 027-82927161; fax: +86 027-82927923. E-mail address: wuhaipeng0701@126.com (H. P. Wu).

${ }^{*}$ Corresponding author. Tel.: +86 731-88822754; fax: +86 731-88823701. E-mail address: zgming@hnu.edu.cn (G. M. Zeng).

ISSN: $1726-2135$ print/1684-8799 online

(C) 2019 ISEIS All rights reserved. doi:10.3808/jei.201900411 the midstream of Changjiang River (Yangtze River). They are the two largest freshwater lakes of China and Ramsar wetlands of international importance (Feng et al., 2013; Wu et al., 2013; Hu et al., 2015; Zeng et al., 2015; Song et al., 2018; Guan et al., 2019). The two lakes are the vital wintering habitats and pathways of migratory birds in East Asia (Wu et al., 2017). The Three-Gorges Dam (TGD, the largest hydroelectric project in the world) was commissioned in 2003, and its reservoir had a total capacity of $393 \times 108 \mathrm{~m}^{3}$ and a surface area of $1,084 \mathrm{~km}^{2}$ (Huang et al., 2015; Wu et al., 2013). As a result of impounding of TGD (Feng et al., 2013; Wang et al., 2013a; Wu et al., 2013; Yu et al., 2019), sand mining (Lai et al., 2014), and climate change (Feng et al., 2014), the dry season of Dongting Lake and Poyang Lake came early after commissioning of TGD (Wu et al., 2015; Wu et al., 2017). The early dry season (EDS) is the leading cause of the need for construction of sluice/dam at the outlets of two lakes to store water in the two lake wetlands (Fan et al., 2008; Li, 2009; Wu et al., 2017). Many studies have been reported about the EDS (Zou et al., 2000; Feng et al., 2013; Wang et al., 2013a; Feng et al., 2014; Lai et al., 2014; Wu et al., 2016; Liu et al., 2018b), but have primarily been focused on the prediction, verification and analysis of the early starting dates (Xu et al., 2012; Wu et al., 2017; Zhang et al., 2019).

However, little is known about the effect of the EDS on migratory birds. It is very important because these lakes are 
crucial wintering habitats and pathways of migratory birds in East Asia (Wu et al., 2017). Another study also argued that the EDS caused the changes of landscape pattern of the two wetlands, which would impact migrating birds of East Asia (Wu et al., 2017). Habitat suitability, can be analyzed using traditional field survey methods or remote sensing techniques, is the capacity of the environment of one region to provide appropriate conditions for wildlife (Tang et al., 2016). A habitat suitability index (HSI) can be calculated, based on the biological and ecological information of the species and the habitat conditions (Yi et al., 2017). Habitat suitability is a sensitive index of evaluating the impact of habitat changes on biota (Hirzel et al., 2002; Elith et al., 2006; Zeng et al., 2013b). Habitat suitability for migratory birds is sensitive to environment changes and human activities, and is often used to evaluate the impact of habitat changes on migratory birds (Tian et al., 2008; Liang et al., 2015; Tang et al., 2016). Therefore, the EDS of the China's two largest freshwater lake wetlands would affect the habitat suitability for migratory birds.

In this study, we used geo-spatial overlay calculation to investigate habitat suitability for Anatidae, Charadriidae, Ardeidae and Laridae (the four main types of migratory birds) of the Dongting Lake and Poyang Lake wetlands in hydrologic year with a normal dry season (NY) and hydrologic year with an EDS (EY), and to analyze the effects of the EDS of the two lake wetlands on habitat suitability for migratory birds. The objectives of this study were: (1) to analyze effects of the EDS of China's two largest freshwater lake wetlands on habitat suitability for migratory birds after the impoundment of TGD; and (2) to provide theoretical support for biology (especially mi- grating birds) protection and management of wetlands around the world.

\section{Study Area and Methods}

\subsection{Study Area}

Dongting Lake (geographic coordinate: $28^{\circ} 30^{\prime} \sim 29^{\circ} 38^{\prime} \mathrm{N}$, $112^{\circ} 18^{\prime} \sim 113^{\circ} 15^{\prime} \mathrm{E}$ ) and Poyang Lake (geographic coordinate: $28^{\circ} 11^{\prime} \sim 29^{\circ} 51^{\prime} \mathrm{N}, 115^{\circ} 31^{\prime} \sim 117^{\circ} 06^{\prime} \mathrm{E}$ ) (Wu et al., 2015), the two largest freshwater lakes in China, are locate at downstream of the TGD and midstream of Changjiang River (Feng et al., 2013; Zeng et al., 2013a; Zhou et al., 2016a; Wu et al., 2017) (Figure 1), which is one of the major rivers around the world and exhibits seasonal variability in the water level and area from monsoon-driven precipitation (Li et al., 2011; Wu et al., 2013; Dai et al., 2016). There is a high water area and water level from May to October (wet season) and a low water area and water level from November to the following April (dry season) (Li et al., 2011; Zhou et al., 2014; Wu et al., 2017). The areas of Dongting Lake and Poyang Lake are about $2,790 \mathrm{~km}^{2}$ and $3,490 \mathrm{~km}^{2}$ in normal wet season (Hu et al., 2015). The two lakes are the key wintering habitats and pathways of migratory birds in East Asia (Zeng et al., 2015), and the important migration routes, spawning grounds and feeding grounds of migratory fishes (Zhou et al., 2016b; Wu et al., 2017). The starting date of dry season of each year after the impoundment of the TGD and annual average starting date of dry season before the impoundment of TGD of Dongting Lake and Poyang Lake are shown on our another paper (Wu et al., 2017). The dry season had an obvious trend of early starting dates in the Dongting

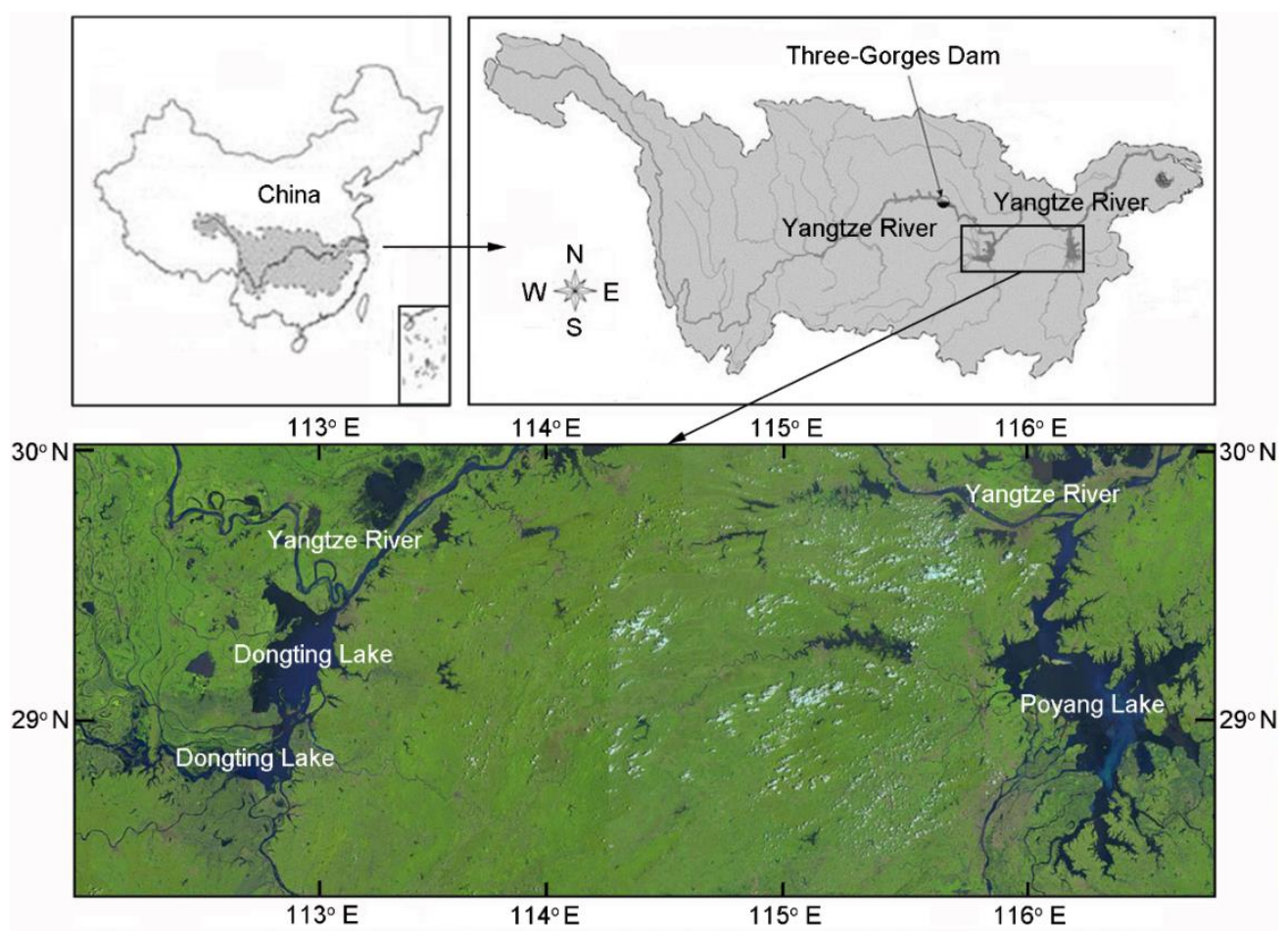

Figure 1. Locations of Dongting Lake, Poyang Lake and Three-Gorges Dam (TGD). 
Lake wetland (3.42 days year ${ }^{-1}$ ) and the Poyang Lake wetland (7.35 days year ${ }^{-1}$ ) from 2000 to 2009 (Feng et al., 2013). And Zou et al. (2000) also predicted that the average starting date of the dry season would arrive 35, 7 and 2 days (low-flow year, median-water year and high-flow year, respectively) earlier in the Dongting Lake wetland in recent years and would arrive more earlier in the 50 years after impoundment of the TGD (Wu et al., 2017).

\subsection{Methods}

According to the previous study (Wu et al., 2017), 2003, 2006 and 2013 hydrologic year (from May to next April), and 2004, 2005 and 2010 hydrologic year were designated as the representatives of EY and NY of Dongting Lake, respectively; 2006, 2007 and 2009 hydrologic year, and 1999, 2001 and 2014 hydrologic year were designated as the representatives of EY and NY of Poyang Lake, respectively. In this study, the grading systems of habitat suitability included poor $(0 \sim 25)$, fair $(25 \sim$ $50)$, good $(50 \sim 75)$, and very good $(75 \sim 100)$. The assessment of habitat suitability for Anatidae, Charadriidae, Ardeidae and Laridae of the two lakes in each hydrologic year was conducted based on per-pixel approaches.

The selection of environmental factors, habitat preference and the factor weightings are vital steps in habitat suitability assessment (Tian et al., 2008; Tang et al., 2016). In this study, the selection of environmental factors, each habitat preference and the factor weightings were assigned based on experts marking (Tamis and Van't Zelfde, 1998; Seoane et al., 2006; Tang et al., 2016) and several studies about habitat suitability for mi- gratory birds at the same and adjacent area (Tian et al., 2008; Yuan et al., 2014; Liang et al., 2015; Tang et al., 2016). Four groups of factors which directly influence the foraging and resting for the migratory birds, including the types of land cover, human disturbances, altitude and gradient, were selected in this study. The Normalized Difference Vegetation Index (NDVI) (indicating landscape diversity) (Lakshmi Kumar et al., 2016) was not selected as environmental factor in this study because of the small scale of the study unit and the problem of band missing of satellite images.

The information of land cover was obtained from our previous research (Wu et al., 2017). The resolution of land cover was $30 \times 30 \mathrm{~m}$, and the spatial extent and the temporal period are shown in the previous article (Wu et al., 2017). The grading system of land cover for the four groups of migratory birds is shown in Table 1 . The indicators of human disturbances include the distance to first grade road (railway, expressway, national road and provincial road), distance to secondary road (county road), distance to urban resident districts and distance to township settlements. These data was obtained with ArcGis 10.2 according to the Baidu Map (http://map.baidu.com/) and BIGMAP (http://www.bigemap.net/). The grading system of human disturbances for the four groups of migratory birds is showing in Table 2. Among the four indicators of human disturbances, the lowest grade was defined the final grade of human disturbances at same place. Altitude and gradient were got from DEM data, which was got from the website: http://www.gsclou d.cn/. The grading system of altitude and gradient for the four groups of migratory birds is shown in Table 2 .

Table 1. Suitability Grade of Land Cover Types of the Two Wetlands for Different Groups of Birds

\begin{tabular}{|c|c|c|c|c|c|c|c|}
\hline Birds & Phragmites & Carex & Phalaris & Sand & Mudflat & Shallow water & Deep water \\
\hline Anatidae & Fair & Very good & Good & Poor & Poor & Good & Poor \\
\hline Charadriidae & Poor & Good & Very good & Poor & Very good & Fair & Poor \\
\hline Ardeidae & Fair & Very good & Good & Poor & Good & Very good & Poor \\
\hline Laridae & Poor & Fair & Good & Poor & Very good & Very good & Good \\
\hline
\end{tabular}

Table 2. Suitability Grade of Human Disturbances, Altitude and Gradient of the Two Wetlands for Different Groups of Birds

\begin{tabular}{|c|c|c|c|c|}
\hline & Poor & Fair & Good & Very Good \\
\hline Distance to first grade road (m) & $0 \sim 600$ & $600 \sim 1200$ & $1200 \sim 2400$ & $>2400$ \\
\hline Distance to secondary road (m) & $0 \sim 240$ & $240 \sim 480$ & $480 \sim 960$ & $>960$ \\
\hline Distance to urban resident districts (m) & $0 \sim 900$ & $900 \sim 1800$ & $1800 \sim 3600$ & $>3600$ \\
\hline Distance to township settlements (m) & $0 \sim 300$ & $300 \sim 600$ & $600 \sim 1200$ & $>1200$ \\
\hline Altitude of Dongting Lake (m) & $<21$ & $>40$ & $28 \sim 40$ & $21 \sim 28$ \\
\hline Altitude of Poyang Lake (m) & $<8$ & $>30$ & $18 \sim 30$ & $8 \sim 18$ \\
\hline Gradient (degree) & $>20$ & $5 \sim 20$ & $1 \sim 5$ & $0 \sim 1$ \\
\hline
\end{tabular}

Table 3. Weights of Each Factor for Different Groups of Birds at the Dongting Lake and Poyang Lake Wetlands

\begin{tabular}{lllll}
\hline Birds & Land cover type & Altitude & Gradient & Human disturbance \\
\hline Anatidae & 0.50 & 0.08 & 0.10 & 0.32 \\
Charadriidae & 0.53 & 0.05 & 0.07 & 0.35 \\
Ardeidae & 0.58 & 0.02 & 0.02 & 0.38 \\
Laridae & 0.60 & 0.01 & 0.01 & 0.38 \\
\hline
\end{tabular}


All data (including the categorical data) was standardized (suitability index), then the habitat suitability index was calculated (Zhang et al., 2017). The weight of each factor for migratory birds is shown in Table 3. The weight was given based on the following factors: 1) different land cover type provided different food and habitat for birds, and land cover type was the most important factor; 2) human disturbance was another important factor; 3) altitude was related to water level fluctuation, and showed the distance to water body and probability of submerged; 4) birds were easier to find natural enemy with lower gradient; 5) the investigated field data of migratory birds in Dongting Lake; 6) life habit of migratory birds; and 7) several studies about habitat suitability assessment for migratory birds at the same and adjacent area (Tian et al., 2008; Yuan et al., 2014; Liang et al., 2015; Tang et al., 2016). A comprehensive index of habitat suitability (Equation (1)), which was a linear function, was calculated using a method of geo-spatial overlay calculation (using ArcGIS 10.2 software):

$$
\mathrm{HSI}_{j}=\sum_{i=1}^{m} W_{i j} f_{i j}
$$

where $\mathrm{HSI}_{j}$ is the HSI for the $j^{\text {th }}(j=1,2, \ldots, 4)$ group of migratory birds; $m$ is the total number of environmental factors; for the $j^{\text {th }}$ group of migratory birds, $W_{i j}$ and $f_{i j}(i=1,2, \ldots, m)$ are the weight and the suitability index of the $i^{\text {th }}$ environmental factor, respectively (Tian et al., 2008).

The aforementioned grading systems of habitat suitability were also adopted for presenting the final integrated index of habitat suitability. Then, Total Area (TA), Largest Patch Index (LPI, the percentage the total area made up by the largest patch) and Mean Patch Size (MPS, the average area of each patch) were calculated for each grade of habitat suitability for each migratory birds group using Fragstats (version 4.2.1) software.

\subsection{Data Analysis}

The significant differences $(p<0.05)$ of indices (TA, LPI and MPS) between EY and NY were tested using one way analysis of variance (ANOVA) for each grade of each migratory birds group. The correlations between each index and the starting date of dry season were analyzed by Pearson correlation analysis for each grade of each migratory birds group. All these analyses were conducted using SPSS (version 19) (Wu et al., 2017).

\section{Results}

The habitat suitability for Anatidae at the Dongting Lake and Poyang Lake in NY and EY are shown on Figure 2. The TA of each grade of habitat suitability (Figure 3 ) indicated that the TA of higher grade of habitat suitability in EY was improved in the both wetlands relative to that of NY. The TA of poor, fair, good and very good grade of habitat suitability for Anatidae at the Dongting Lake accounted for 1.58, 33.85, 39.34 , and $25.22 \%$ of the total area in NY and $1.51,32.42$, 35.51 , and $30.56 \%$ of the total area in EY, respectively. That of
Poyang Lake accounted for $1.78,52.65,24.28$, and $21.29 \%$ of the total area in NY and 1.48, 40.72, 34.42, and $23.39 \%$ of the total area in EY, respectively. It was significant that the increases of very good grade of habitat suitability for Anatidae at the Dongting Lake wetland and the good grade of that at the Poyang Lake wetland. The results of LPI (Figure 4) and MPS (Figure 5) in-dicated that the patch size of higher grade of habitat suitability of both wetlands had an increasing tendency in EY. The results of Pearson correlation analysis between each index and the starting date of dry season are showing in Table 4. On the whole, the EDS could improve the habitat suitability for Anati-dae at Dongting Lake and Poyang Lake wetlands.

The habitat suitability for Charadriidae in NY and EY are shown on Figure S1. The TA of each grade of habitat suitability (Figure 3) indicated that there were no significant coincident differences between that of NY and EY. The TA of poor, fair, good and very good grade of habitat suitability for Charadriidae at the Dongting Lake accounted for $1.25,27.68,40.72$, and $30.35 \%$ of the total area in NY and 1.36, 33.61, 39.60, and $25.43 \%$ of the total area in EY, respectively. That of Poyang Lake accounted for $1.32,35.13,36.26$, and $27.28 \%$ of the total area in NY and 1.20, 31.11, 39.73, and $27.96 \%$ of the total area in EY, respectively. The results of LPI (Figure 4) and MPS (Figure 5) indicated that there was no significant difference between the patch sizes of each grade of habitat suitability for Charadriidae of NY and EY. On the whole, the EDS had no significant influence on the habitat suitability for Charadriidae at the two wetlands.

The habitat suitability for Ardeidae at both wetlands in NY and EY are shown on Figure S2. The TA of each grade of habitat suitability (Figure 3) indicated that there were also no signifycant coincident differences between that of NY and EY at both wetlands. The TA of poor, fair, good and very good grade of habitat suitability for Ardeidae at the Dongting Lake accounted for $1.82,16.64,47.72$, and $33.82 \%$ of the total area in NY and 1.91, 17.98, 43.11, and $37.00 \%$ of the total area in EY, respectively. That of Poyang Lake accounted for 1.95, $30.52,35.40$, and $32.13 \%$ of the total area in NY and 1.77 , $26.20,35.78$, and $36.25 \%$ of the total area in EY, respectively. The results of LPI (Figure 4) and MPS (Figure 5) indicated that there was also no significant difference between the patch sizes of each grade of habitat suitability for Ardeidae of NY and EY in the both wetlands. On the whole, the EDS also had no significant influence on the habitat suitability for Ardeidae at the Dongting Lake and Poyang Lake wetlands.

The habitat suitability for Laridae at the Dongting Lake and Poyang Lake in NY and EY are shown on Figure S3. The TA of each grade of habitat suitability (Figure 3 ) indicated that some area of very good grade of habitat suitability for Laridae was turn into good grade in the both wetlands. The TA of poor fair, good and very good grade of habitat suitability for Laridae suitability for Laridae at the Dongting Lake accounted for 0.57 , at the Dongting Lake accounted for $0.57,20.92,53.82$, and $24.69 \%$ of the total area in NY and $0.55,20.22,59.53$, and $19.70 \%$ of the total area in EY, respectively. That of Poyang Lake accounted for $0.48,9.94,59.09$, and $30.49 \%$ of the total area in NY and $0.47,9.76,65.09$, and $24.68 \%$ of the total area 
(a) Normal hydrologic year (NY) of Dongting Lake
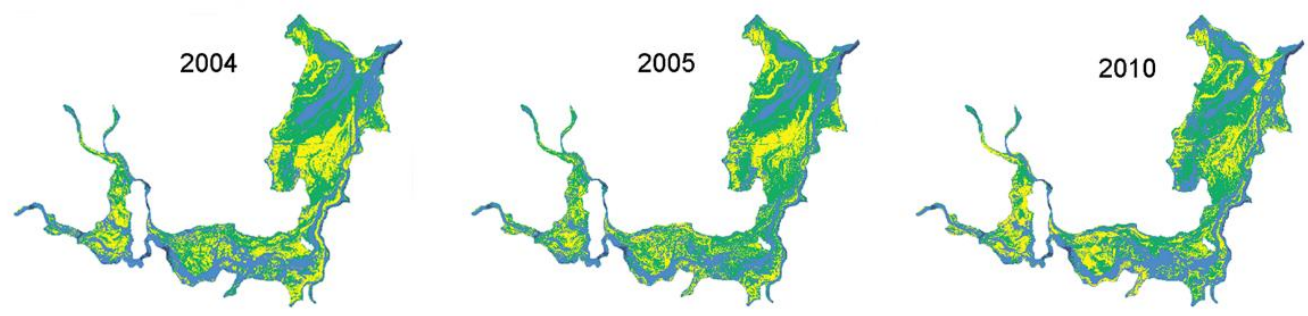

(b) Hydrologic year with early dry season (EY) of Dongting Lake
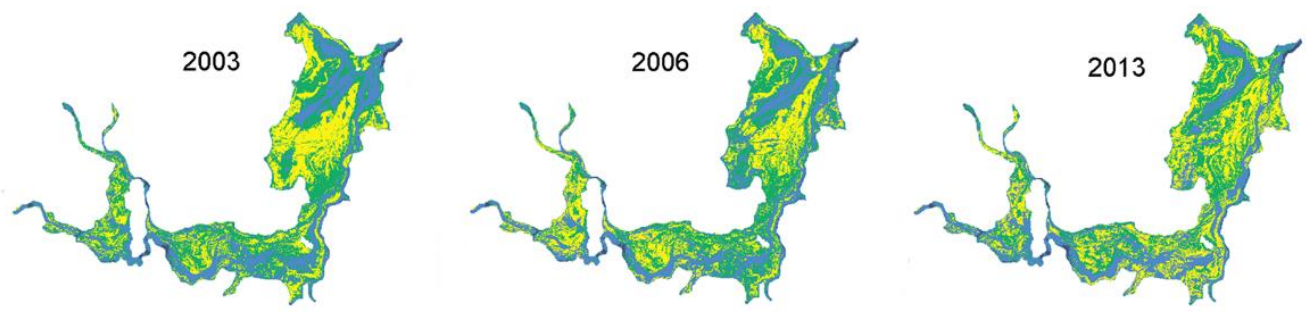

(c) Normal hydrologic year (NY) of Poyang Lake
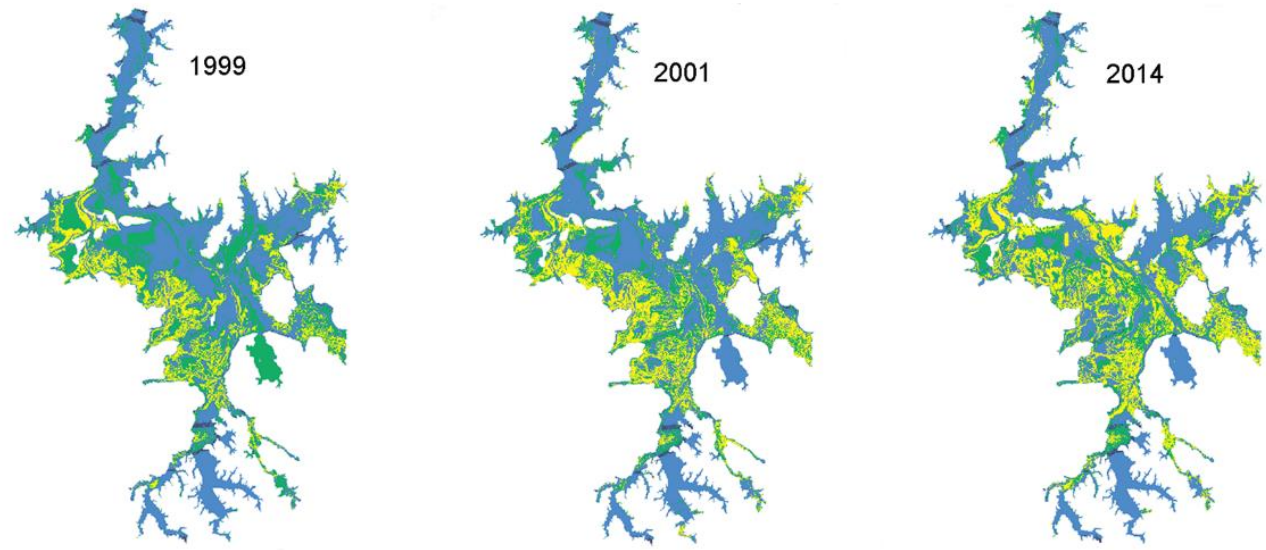

(d) Hydrologic year with early dry season (EY) of Poyang Lake

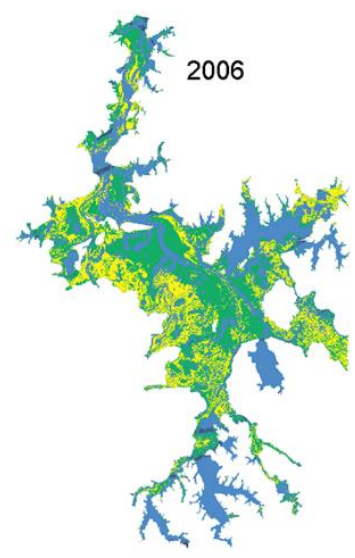

Poor

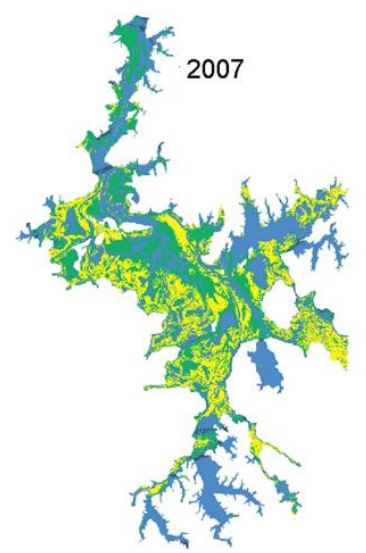

Fair

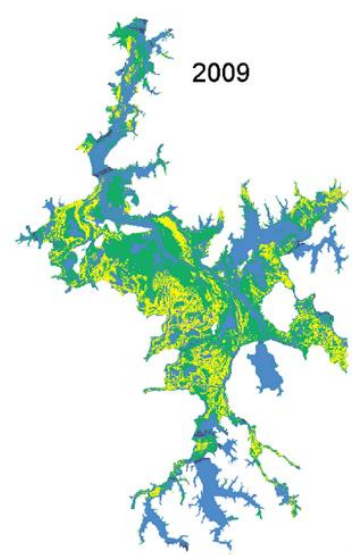

Very Good

Figure 2. The habitat suitability maps for Anatidae of (a) normal hydrologic year (NY) of Dongting Lake, (b) hydrologic year with early dry season (EY) of Dongting Lake, (c) normal hydrologic year (NY) of Poyang Lake and (d) hydrologic year with early dry season (EY) of Poyang Lake. The habitat suitability maps for Charadriidae, Ardeidae and Laridae are showing in Supplementary Material (Appendix Figures S1 S3). 
(a) Anatidae
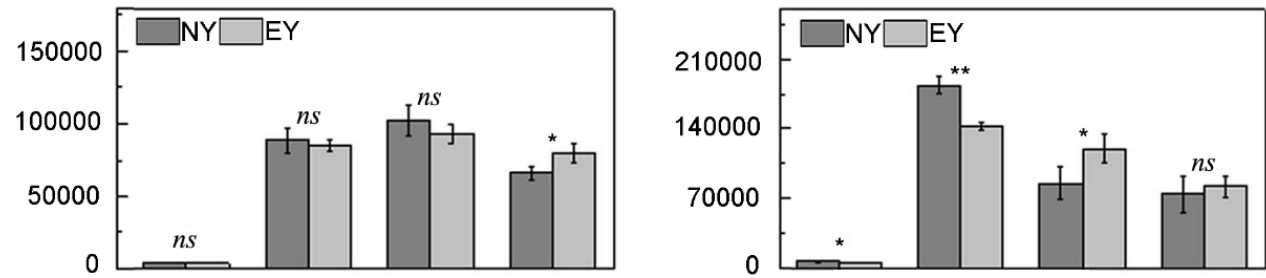

(b) Charadriidae
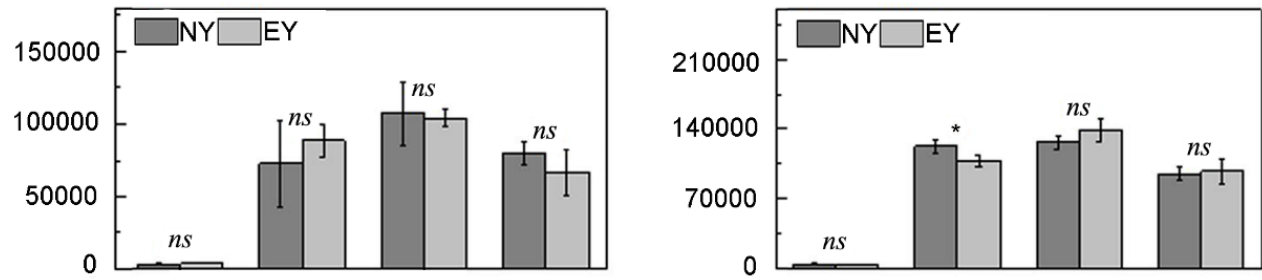

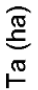

(c) Ardeidae
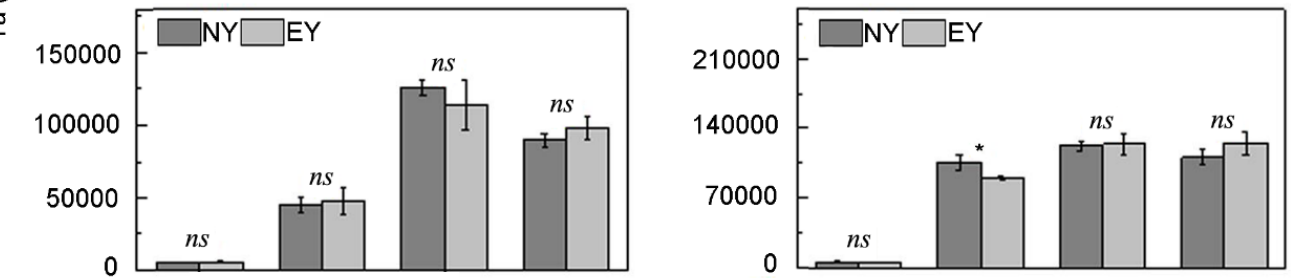

(d) Laridae
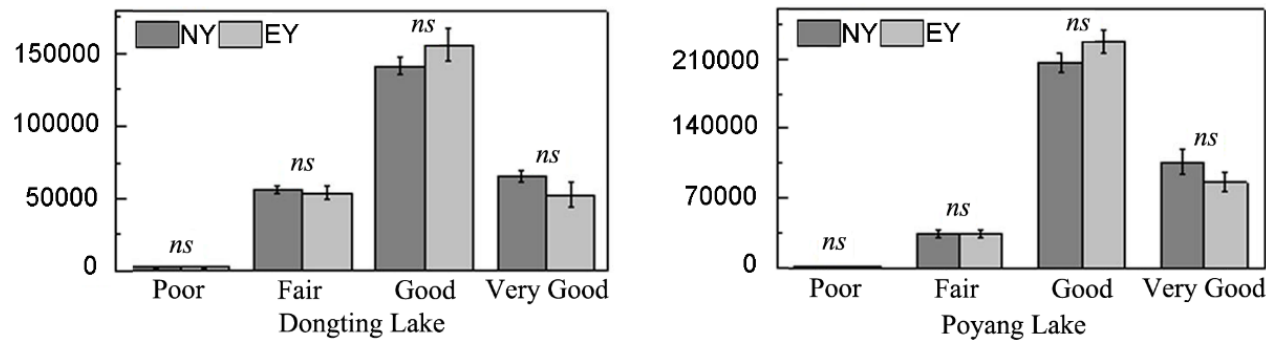

Figure 3. The TA (total area) of each grade of habitat suitability for (a) Anatidae, (b) Charadriidae, (c) Ardeidae and (d) Laridae of NY and EY in Dongting Lake and Poyang Lake, respectively. Significant differences between EY and NY are indicated by $* * *(p$ $<0.001), * *(p<0.01), *(p<0.05)$, while ns indicated no significant difference $(p>0.05)$.

in EY, respectively. The decreases of TA of very good grade of habitat suitability for Laridae at the Dongting Lake and Poyang Lake wetland were almost significant $(p=0.079$ and 0.092 respectively), and the increases of good grade were also almost significant ( $p=0.122$ and 0.077 respectively). The results of LPI (Figure 4) and MPS (Figure 5) indicated that the patch size of very good grade of habitat suitability of both wetland had a decreasing tendency (not significant) in EY. On the whole, the EDS had an almost significant adverse effect on the habitat suitability for Laridae at Dongting Lake and Poyang Lake wetlands.

\section{Discussions}

\subsection{Determination of Habitat Suitability for Birds}

In this study, we determined the habitat suitability for the four main types of migratory birds (Anatidae, Charadriidae,
Ardeidae and Laridae) of Dongting Lake and Poyang Lake in 3 NYs and 3 EYs, using a method of geo-spatial overlay calculation. The method of overlaying raster map layers of environmental factors with different weights is the most commonly used method (Tian et al., 2008; Feng et al., 2010; Guigoz et al., 2017). It could overcome the difficulty in field surveys data lacking and time consuming of field surveys (Barrett and Curtis, 1999; Zohmann et al., 2013; Huang et al., 2016). Four groups of environmental factors, including the types of land cover, human disturbances (including the distance to first grade road, distance to secondary road, distance to urban resident districts and distance to township settlements), altitude and gradient, were selected in this study. Food resources also have important effects on the habitat suitability for birds (Tamisier and Grillas, 1994; Huang et al., 2008; Gan et al., 2009). Although food factor was not directly considered in this study because of the absence of these data, it was indirectly considered using the 
higher weight of the types of land cover, which was because different types of land cover provided different food for the migratory birds (Angradi et al., 2001; Gan et al., 2009). The habitat suitability for birds was calculated based on experts marking (Tamis and Van't Zelfde, 1998; Seoane et al., 2006; Tang et al., 2016) and several studies at the same and adjacent area (Tian et al., 2008; Yuan et al., 2014; Liang et al., 2015; Tang et al., 2016), and its result should be credible.

\subsection{Effect of EDS on Habitat Suitability}

Dongting Lake and Poyang Lake wetlands are the most important wintering area and pathways for migratory birds in East Asia and also support many rare and threatened species (Wu et al., 2013; Zeng et al., 2015; Dai et al., 2016; Tang et al., 2016). Therefore, it is vital to quickly monitor and assess the changes in the habitat quality and find out the reasons of the changes (Xia et al., 2015; Tang et al., 2016). The EDS is one of the main hydrological changes in the two lakes after the com-missioning of TGD (Feng et al., 2013; Lai et al., 2014; Wu et al., 2015; Wu et al., 2017). The current research showed that the EDS gave rise to the changes of land cover or landscape pattern in the two lake wetlands, which would affect the habitat suitability for migratory birds (Wu et al., 2017). In fact, other

(a) Anatidae
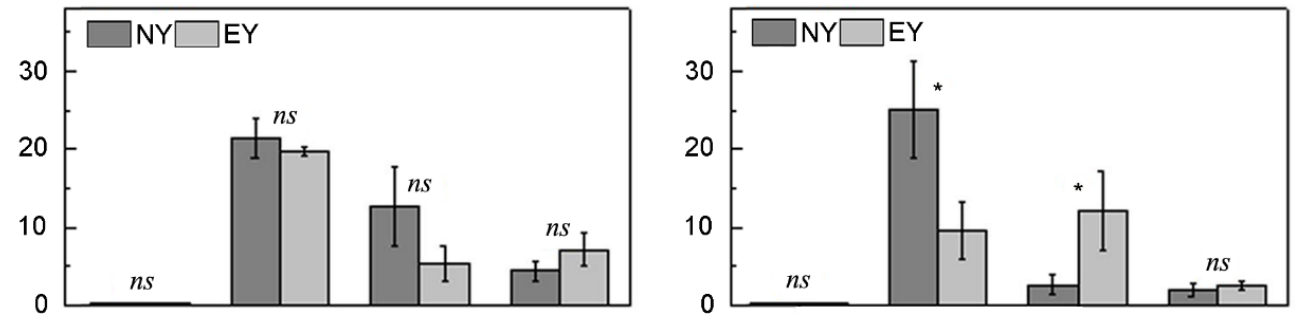

(b) Charadriidae
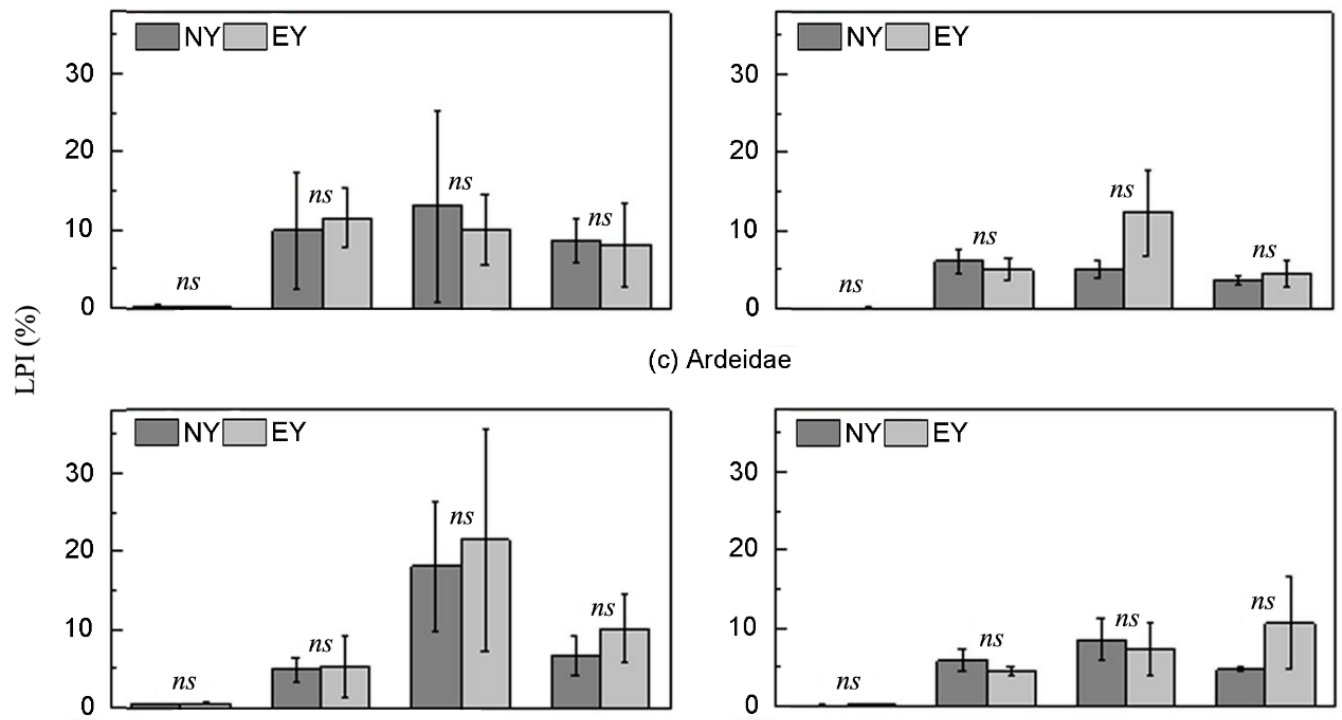

(c) Ardeidae

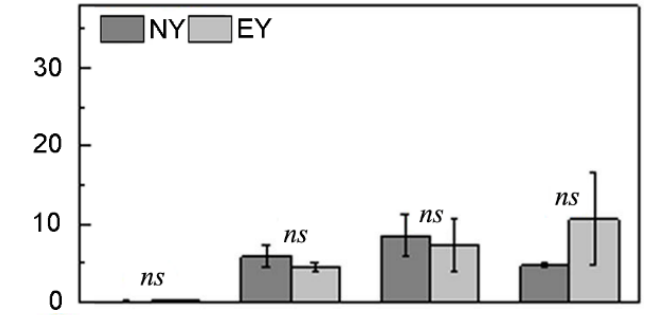

(d) Laridae
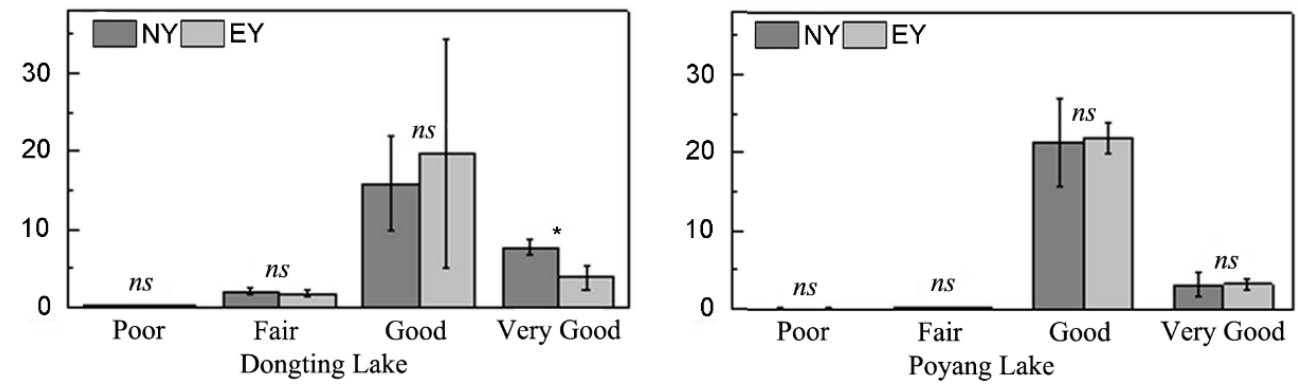

Figure 4. The LPI (Largest patch index) of each grade of habitat suitability for (a) Anatidae, (b) Charadriidae, (c) Ardeidae and (d) Laridae of NY and EY in Dongting Lake and Poyang Lake, respectively. 
(a) Anatidae
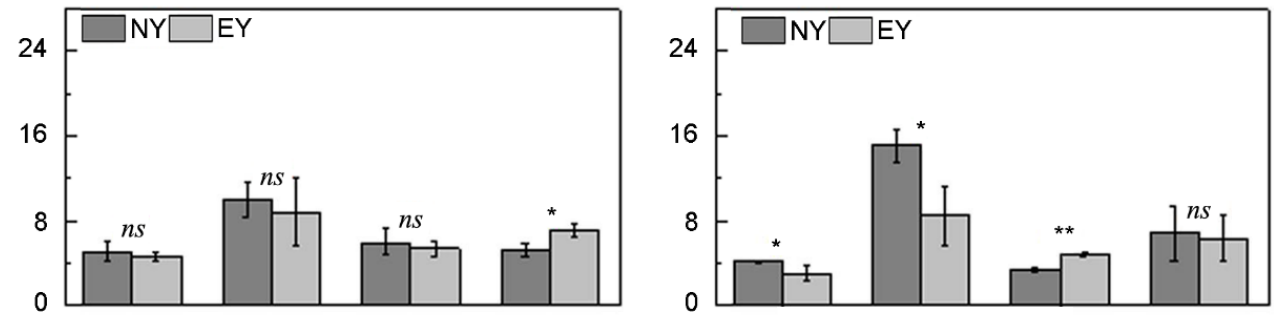

(b) Charadriidae
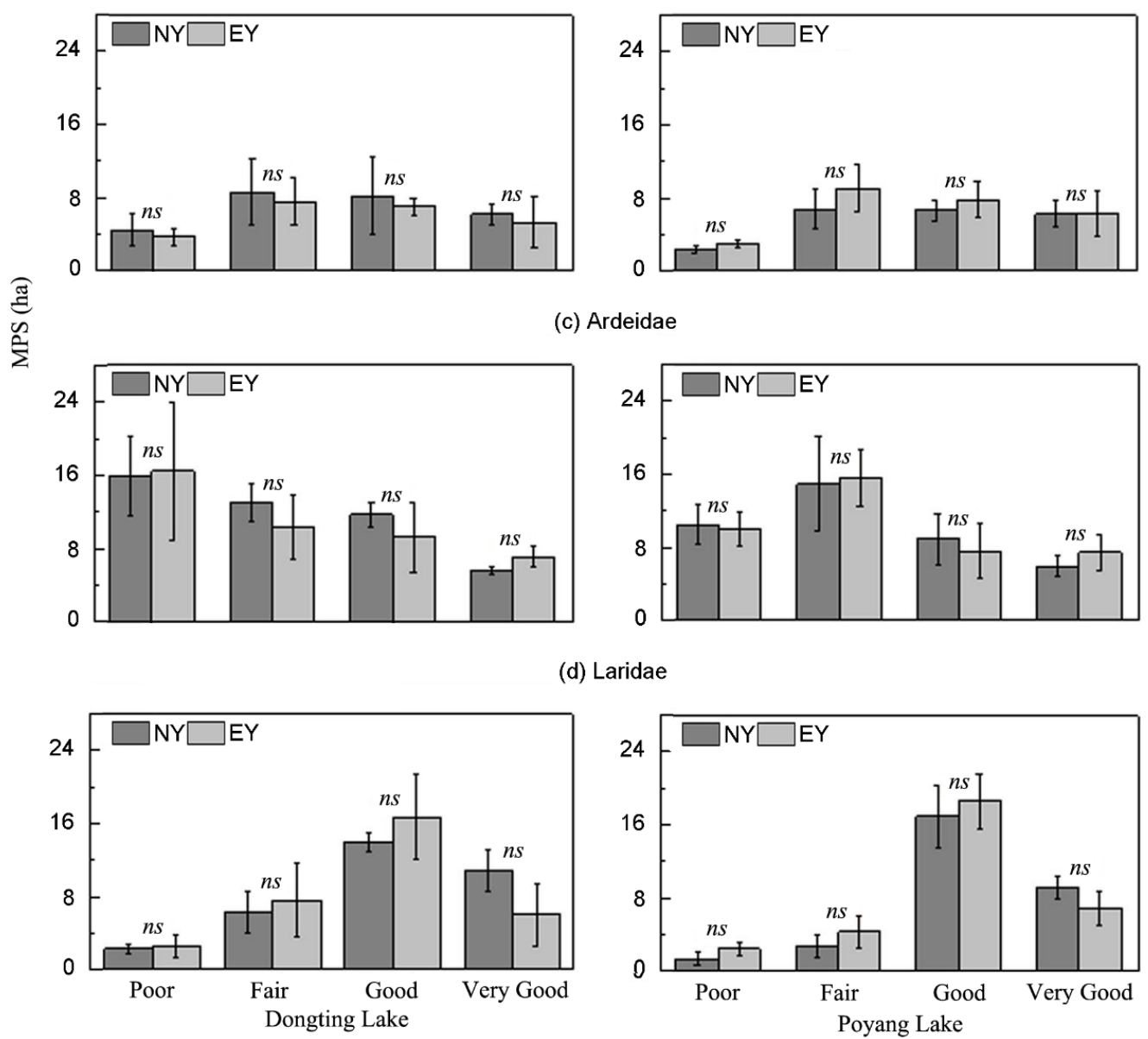

(c) Ardeidae

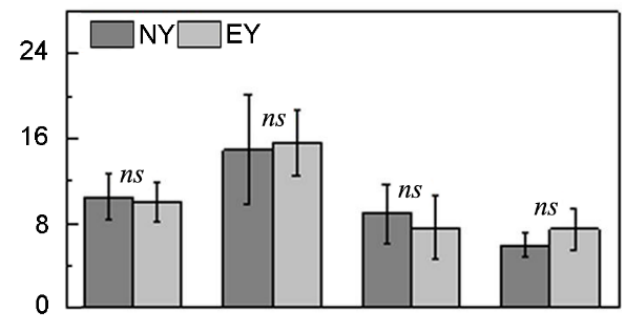

(d) Laridae

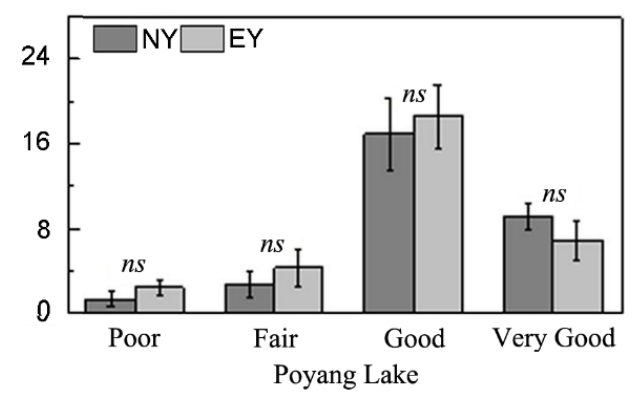

Figure 5. The MPS (Mean patch size) of each grade of habitat suitability for (a) Anatidae, (b) Charadriidae, (c) Ardeidae and (d) Laridae of NY and EY in Dongting Lake and Poyang Lake, respectively.

studies also found that the hydrological conditions highly affected habitat suitability in this region (Wang et al., 2013b; Yuan et al., 2014; Tang et al., 2016; Zhang et al., 2016).

In this study, we found that the EDS: 1) could improve the habitat suitability for Anatidae; 2) had no significant influence on the habitat suitability for Charadriidae and Ardeidae; and 3) had an almost obvious adverse effect on the habitat suitability for Laridae. Comparing with habitat suitability grade of land cover for the four groups of migratory birds, we could find that these changes were consistent with the expandsion of Carex and Phalaris to mudflat zone (Wu et al., 2017). This was because different land cover provided different habitat and food for migratory birds, and had different habitat suitability grade for the four groups of migratory birds (Angradi et al., 2001; Tang et al., 2008; Gan et al., 2009). Other studies also found that land cover (including vegetation distribution) could affect the habitat suitability for migratory birds in wetland (Yuan et al., 2014; Tang et al., 2016).

Although our results displayed that the EDS had an almost obvious adverse effect on the habitat suitability for Laridae in the two lake wetlands, we still considered that the EDS could have a significant adverse effect on the habitat suitability for 
Table 4. Correlation Coefficient between Each Index of the Two Lakes and Their Starting Day of Dry Season

\begin{tabular}{|c|c|c|c|c|c|c|c|}
\hline \multirow{2}{*}{ Birds } & \multirow{2}{*}{ Grade } & \multicolumn{3}{|c|}{ Dongting Lake } & \multicolumn{3}{|c|}{ Poyang Lake } \\
\hline & & TA & LPI & MPS & TA & LPI & MPS \\
\hline \multirow[t]{4}{*}{ Anatidae } & Poor & $0.219^{0.676}$ & $-0.182^{0.730}$ & $0.301^{0.562}$ & $0.966^{0.002}$ & $0.538^{0.271}$ & $0.944^{0.005}$ \\
\hline & Fair & $-0.132^{0.803}$ & $0.217^{0.679}$ & $0.448^{0.373}$ & $0.912^{0.011}$ & $0.782^{0.066}$ & $0.914^{0.011}$ \\
\hline & Good & $0.661^{0.153}$ & $0.858^{0.029}$ & $0.678^{0.139}$ & $-0.770^{0.073}$ & $-0.822^{0.045}$ & $-0.908^{0.012}$ \\
\hline & Very Good & $-0.621^{0.188}$ & $-0.173^{0.743}$ & $-0.660^{0.154}$ & $-0.285^{0.585}$ & $-0.460^{0.358}$ & $0.392^{0.443}$ \\
\hline \multirow[t]{4}{*}{ Charadriidae } & Poor & $-0.529^{0.280}$ & $0.091^{0.865}$ & $0.689^{0.130}$ & $0.529^{0.281}$ & $-0.058^{0.914}$ & $-0.524^{0.286}$ \\
\hline & Fair & $-0.551^{0.258}$ & $-0.197^{0.709}$ & $0.585^{0.222}$ & $0.691^{0.128}$ & $0.124^{0.815}$ & $-0.352^{0.494}$ \\
\hline & Good & $0.344^{0.505}$ & $0.509^{0.302}$ & $0.354^{0.491}$ & $-0.575^{0.233}$ & $-0.924^{0.008}$ & $-0.241^{0.646}$ \\
\hline & Very Good & $0.543^{0.266}$ & $0.048^{0.928}$ & $0.422^{0.404}$ & $-0.049^{0.927}$ & $-0.146^{0.783}$ & $0.353^{0.492}$ \\
\hline \multirow[t]{4}{*}{ Ardeidae } & Poor & $-0.191^{0.716}$ & $-0.005^{0.993}$ & $0.139^{0.793}$ & $0.628^{0.182}$ & $-0.179^{0.735}$ & $0.229^{0.663}$ \\
\hline & Fair & $-0.355^{0.490}$ & $-0.104^{0.845}$ & $0.717^{0.109}$ & $0.827^{0.042}$ & $0.384^{0.453}$ & $-0.094^{0.859}$ \\
\hline & Good & $0.376^{0.462}$ & $-0.237^{0.651}$ & $0.602^{0.206}$ & $-0.079^{0.882}$ & $0.446^{0.376}$ & $0.596^{0.212}$ \\
\hline & Very Good & $-0.327^{0.528}$ & $0.041^{0.939}$ & $-0.709^{0.114}$ & $-0.638^{0.172}$ & $-0.850^{0.032}$ & $-0.324^{0.531}$ \\
\hline \multirow[t]{4}{*}{ Laridae } & Poor & $-0.216^{0.681}$ & $0.711^{0.113}$ & $0.262^{0.615}$ & $-0.024^{0.964}$ & $-0.201^{0.703}$ & $-0.508^{0.304}$ \\
\hline & Fair & $-0.240^{0.648}$ & $0.416^{0.412}$ & $0.213^{0.685}$ & $-0.193^{0.715}$ & $-0.527^{0.282}$ & $-0.349^{0.498}$ \\
\hline & Good & $-0.351^{0.495}$ & $0.119^{0.822}$ & $-0.065^{0.903}$ & $-0.656^{0.157}$ & $-0.073^{0.891}$ & $-0.233^{0.657}$ \\
\hline & Very Good & $0.531^{0.278}$ & $0.829^{0.041}$ & $0.843^{0.035}$ & $0.697^{0.124}$ & $0.065^{0.903}$ & $0.688^{0.131}$ \\
\hline
\end{tabular}

* The significance of the correlation is shown by superscript.

** The significant correlation coefficients are shown in bold.

Laridae. This is because that: 1) only mudflat and shallow water provided very good habitat for Laridae. But the area of shallow water was related to water level (Yang et al., 2010; Cai et al., 2012; Hu et al., 2015; Wu et al., 2017). If the influence of shallow water was excluded, the adverse effect of EDS on the habitat suitability for Laridae was very likely significant; 2) some studies considered that the lead time of the two lakes would increase in 50 years after impoundment of the TGD (Zou et al., 2000; Feng et al., 2013; Wu et al., 2015; Wu et al., 2017). The adverse effect of EDS on the habitat suitability for Laridae will be more obvious with the increase in lead time of the two lakes. Therefore, we argued that the effect of EDS on the habitat suitability for Laridae would be significant in the future.

Besides, the assessment of habitat suitability is not constant for different migratory birds, and the environmental factors and weights need to be adjusted (based on sufficient research) for each species (Tian et al., 2008; Lee et al.,2016; Tang et al., 2016). This approach is thus greatly suitable for providing spatial information to assist with the bird conservation and management in wetlands around the world (especially the lake wetlands in the middle and lower reaches of Changjiang River). From this study, especially the habitat suitability maps in NYs and EYs, we could recognize the priority areas for habitat protection and restoration. Some protection/restoration measures (such as optimize the hydrological conditions) for protecting wintering migratory bird populations in the priority areas will be further studied.

\section{Conclusions}

This paper showed that the EDS in Dongting Lake and Poyang Lake wetlands 1) improved the habitat suitability for Anatidae: the TA of higher grade of habitat suitability was improved, and the patch sizes of higher grade of habitat suitability also had a tendency of increasing; 2) had no significant influence on the habitat suitability for Charadriidae and Ardeidae at the two wetlands; and 3) had an almost significant adverse effect (would be significant in fact and in the future) on the habitat suitability for Laridae: some area of very good grade of habitat suitability for Laridae was turned into good grade, and the patch sizes of very good grade of habitat suitability of both wetlands had a decreasing tendency.

Acknowledgements. This research was financially supported by the National Key R\&D Program of China (2017YFC0404502), the Fundamental Research Funds for National Central Public Welfare Research Institutes (CKSF2017001/SZ), the National Natural Science Foundation of China (51809011, 51521006, 51378190 and 51509014), the Program for Chang-jiang Scholars and Innovative Research Team in University (IRT-13R17), and National Public Research Institutes for Basic R\&D Operating Expenses Special Project (CKSF2017061/SZ).

\section{References}

Angradi, T.R., Hagan, S.M., and Able, K.W. (2001). Vegetation type and the intertidal macroinvertebrate fauna of a brackish marsh: Phragmites vs. Spartina. Wetlands, 21(1), 75-92. https://doi.org/10. 1672/0277-5212(2001)021[0075:VTATIM]2.0.CO;2

Auble, G.T., Friedman, J.M., and Scott, M.L. (1994). Relating riparian vegetation to presentand future streamflows. Ecol. Appl., 4(3), 544554. https://doi.org/10.2307/1941956

Bancroft, G.T., Gawlik, D.E., and Rutchey, K. (2002). Distribution of wading birds relative to vegetation and water depths in the northern Everglades of Florida, USA. Waterbirds, 25(3), 265-277. https://doi. org/10.1675/1524-4695(2002)025[0265:DOWBRT]2.0.CO;2

Barrett, E.C. and Curtis, L.F. (1999). Introduction to Environmental Remote Sensing. Stanley Thornes, Cheltenham.

Cai, Q., Huang, L., Liang, J., Li, X., Long, Y., Xiao, Y., Liu, K., Xie, G., and Zeng, G. (2012). Estimation of the water volume of the Dongting Lake with TERRA/MODIS data. J. Hunan Univ. Nat. Sci., 39, 64-69. 
Dai, J., Wu, H., Zhang, C., Zeng, G., Liang, J., Guo, S., Li, X., Huang, L., Lu, L., and Yuan, Y. (2016). Responses of soil microbial biomass and bacterial community structure to closed-off management (an ecological natural restoration measures): A case study of Dongting Lake wetland, middle China. J. Biosci. Bioeng., 122(3), 345-350. https://doi.or g/10.1016/j.jbiosc.2016.03.001

Elith, J., Graham, C.H., Anderson, R.P., Dudik, M., Ferrier, S., Guisan, A., Hijmans, R.J., Huettmann, F., Leathwick, J.R., Lehmann, A., Li, J., Lohmann, L.G., Loiselle, B.A., Manion, G., Moritz, C., Nakamura, M., Nakazawa, Y., Overton, J.M., Peterson, A.T., Phillips, S.J., Richardson, K., Scachetti-Pereira, R., Schapire, R.E., Soberon, J., Williams, S., Wisz, M.S., and Zimmermann, N.E. (2006). Novel methods improve prediction of species' distributions from occurrence data. Ecography, 29(2), 129-151. https://doi.org/10.1111/j. 2006.0906-7590.04596.x

Fan, T., Liu, Y., Feng, B., Zeng, G., Yang, C., Zhou, M., Zhou, H., Tan, Z., and Wang, X. (2008). Biosorption of cadmium(II), zinc(II) and lead(II) by Penicillium simplicissimum: Isotherms, kinetics and thermodynamics. J. Hazard. Mater, 160(2-3), 655-661. https://doi. org/10.1016/j.jhazmat.2008.03.038

Feng, L., Hu, C., and Chen, X. (2014). Dramatic Inundation Changes of China's Two Largest Freshwater Lakes: Natural Process or Influenced by the Three Gorges Dam? A Revisit. Environ. Sci. Technol., 48(3), 2088-2089. https://doi.org/10.1021/es500042k

Feng, L., Hu, C., Chen, X., and Zhao, X. (2013). Dramatic Inundation Changes of China's Two Largest Freshwater Lakes Linked to the Three Gorges Dam. Environ. Sci. Technol., 47(17), 9628-9634. https://doi.org/10.1021/es4009618

Feng, Y., Gong, J.L., Zeng, G.M., Niu, Q.Y., Zhang, H.Y., Niu, C.G., Deng, J.H., and Yan, M. (2010). Adsorption of Cd (II) and Zn (II) from aqueous solutions using magnetic hydroxyapatite nanoparticles as adsorbents. Chem. Eng. J., 162(2), 487-494. https://doi. org/10.1016/j.cej.2010.05.049

Gan, X.J., Cai, Y.T., Choi, C.Y., Ma, Z.J., Chen, J.K., and Li, B. (2009). Potential impacts of invasive Spartina alterniflora on spring bird communities at Chongming Dongtan, a Chinese wetland of international importance. Estuar. Coast. Shelf Sci., 83(2), 211-218. http s://doi.org/10.1016/j.ecss.2009.03.026

Guan, Y., Huang, G., Liu, L., Huang, C. Z., and Zhai, M. (2019). Ecological network analysis for an industrial solid waste metabolism system. Environ. Pollut., 244, 279-287, https://doi.org/10.1016/j. envpol.2018.10.052

Guigoz, Y., Giuliani, G., Nonguierma, A., Lehmann, A., Mlisa, A., and Ray, N. (2017). Spatial data infrastructures in Africa: A gap analysis. J. Environ. Inf., 30(1), 53-62.

Hirzel, A.H., Hausser, J., Chessel, D., and Perrin, N. (2002). Ecological-niche factor analysis: How to compute habitat-suitability maps without absence data? Ecology, 83(7), 2027-2036. https://doi. org/10.1890/0012-9658(2002)083[2027:ENFAHT]2.0.CO;2

Hu, Y.X., Huang, J.L., Du, Y., Han, P.P., Wang, J.L., and Huang, W. (2015). Monitoring wetland vegetation pattern response to waterlevel change resulting from the Three Gorges Project in the two largest freshwater lakes of China. Ecol. Eng., 74, 274-285. https: //doi.org/10.1016/j.ecoleng.2014.10.002

Huang, D.L., Zeng, G.M., Feng, C.L., Hu, S., Jiang, X.Y., Tang, L., Su, F.F., Zhang, Y., Zeng, W., and Liu, H.L. (2008). Degradation of lead-contaminated lignocellulosic waste by phanerochaete chrysospo-rium and the reduction of Lead Toxicity. Environ. Sci. Technol., 42 (13), 4946-4951. https://doi.org/10.1021/es800072c

Huang, L., Fang, H., and Reible, D. (2015). Mathematical model for interactions and transport of phosphorus and sediment in the Three Gorges Reservoir. Water Res., 85(15), 393-403. https://doi.org/10. 1016/j.watres.2015.08.049

Huang, W., Baetz, B.W., and Razavi, S. (2016). A GIS-based integer programming approach for the location of solid waste collection depots. J. Environ. Inf., 28(1), 39-44. https://doi.org/10.3808/jei.
201600342

Lai, X.J., Shankman, D., Huber, C., Yesou, H., Huang, Q., and Jiang, J.H. (2014). Sand mining and increasing Poyang Lake's discharge ability: A reassessment of causes for lake decline in China. $J$. Hydrol., 519, 1698-1706. https://doi.org/10.1016/j.jhydrol.2014.09. 058

Lakshmi Kumar, T.V., Uma, R., Koteswara Rao, K., Barbosa, H., Prabha Jothi, E., and Patnaik, K.V. K.R.K. (2016). Variability in MODIS NDVI in relation to southwest monsoon over western Ghats, India. J. Environ. Inf., 27(1), 52-61. https://doi.org/10.3808 /jei.201500320

Lee, C., Kim, K., Park, Y., and Lee, H. (2016). GIS-based reach file generation for efficient TMDLs implementation. J. Environ. Inf., 28(1), 45-60. https://doi.org/10.3808/jei.2016 00336

Li, J. (2009). CHINA Scientists line up against dam that would alter protected wetlands. Science, 326, 508-509. https://doi.org/10.1126/ science.326_508

Li, Q.F., Yu, M.X., Lu, G.B., Cai, T., Bai, X., and Xia, Z.Q. (2011). Impacts of the Gezhouba and Three Gorges reservoirs on the sediment regime in the Yangtze River, China. J. Hydrol., 403(3-4), 224-233. https://doi.org/10.1016/j.jhydrol.2011.03.043

Liang, J., Hua, S.S., Zeng, G.M., Yuan, Y.J., Lai, X., Li, X.D., Li, F., Wu, H.P., Huang, L., and Yu, X. (2015). Application of weight method based on canonical correspondence analysis for assessment of Anatidae habitat suitability: A case study in East Dongting Lake, Middle China. Ecol. Eng., 77, 119-126. https://doi.org/10.1016/j. ecoleng.2015.01.016

Ligon, F.K., Dietrich, W.E., and Trush, W.J. (1995). Downstream ecological effects of dams: a geomorphic perspective. Bioscience, 45(3), 183-192. https://doi.org/10.2307/1312557

Liu, L., Huang, C. Z., Huang, G., Baetz, B., and Pittendrigh, S. M. (2018). How a carbon tax will affect an emission-intensive economy: A case study of the Province of Saskatchewan, Canada. Energy, 159, 817-826, https://doi.org/10.1016/j.energy.2018.06.163

Liu, L., Huang, G., Baetz, B., Huang, C. Z., and Zhang, K. (2018). A factorial ecologically-extended input-output model for analyzing urban GHG emissions metabolism system. J. of Clean. Prod., 200, 922-933, https://doi.org/10.1016/j.jclepro.2018.07.298

Milly, P.C.D., Wetherald, R.T., Dunne, K.A., and Delworth, T.L. (2002). Increasing risk of great floods in a changing climate. Nature, 415, 514-517. https://doi.org/10.1038/415514a

Seoane, J., Justribo, J.H., Garcia, F., Retamar, J., Rabadan, C., and Atienza, J.C. (2006). Habitat-suitability modelling to assess the effects of land-use changes on Dupont's lark Chersophilus duponti: A case study in the Layna Important Bird Area. Biol. Conserv. 128(2), 241-252. https://doi.org/10.1016/j.biocon.2005.09.032

Smith, S.M., Gawlik, D.E., Rutchey, K., Crozier, G.E., and Gray, S. (2003). Assessing drought-related ecological risk in the Florida Everglades. J. Environ. Manage., 68(4), 355-366. https://doi.org/10. 1016/S0301-4797(03)00102-6

Song, P., Huang, G., An, C., Shen, J., Zhang, P., Chen, X., Shen, J., Yao, Y., Zheng, R., and Sun, C. (2018). Treatment of rural domestic wastewater using multi-soil-layering systems: Performance evaluation, factorial analysis and numerical modeling. Sci. Total Environ., 644, 536-546, https://doi.org/10.1016/j.scitotenv.2018.06.331

Tamis, W.L.M., and Van't Zelfde, M. (1998). An expert habitat suitability model for the disaggregation of bird survey data - Bird counts in the Netherlands downscaled from atlas block to kilometre cell. Landscape Urban Plan., 40(4), 269-282. https://doi.org/10.10 16/S0169-2046(97)00092-3

Tamisier, A., and Grillas, P. (1994). A review of habitat changes in the Camargue-an assessment of of the effects of the loss of biological diversity on the wintering waterfowl community. Biol. Conserv., 70(1), 39-47. https://doi.org/10.1016/0006-3207(94)90297-6

Tang, L., Zeng, G.-M., Shen, G.L., Li, Y.P., Zhang, Y., and Huang, D.L. (2008). Rapid detection of picloram in agricultural field samples using a disposable immunomembrane-based wlectrochemical aensor. 
Environ. Sci. Technol., 42(4), 1207-1212. https://doi.org/10.1021/es 7024593

Tang, X.G., Li, H.P., Xu, X.B., Yang, G.S., Liu, G.H., Li, X.Y., and Chen, D.Q. (2016). Changing land use and its impact on the habitat suitability for wintering Anseriformes in China's Poyang Lake region. Sci. Total Environ., 557-558(1), 296-306. https://doi.org/10. 1016/j.scitotenv.2016.03.108

Tian, B., Zhou, Y.X., Zhang, L.Q., and Yuan, L. (2008). Analyzing the habitat suitability for migratory birds at the Chongming Dongtan Nature Reserve in Shanghai, China. Estuar. Coast. Shelf Sci, 80(2), 296-302. https://doi.org/10.1016/j.ecss.2008.08.014

Wang, J., Sheng, Y.W., Gleason, C.J., and Wada, Y. (2013a). Downstream Yangtze River levels impacted by Three Gorges Dam. Environ Res. Lett., 8(4), 4012. https://doi.org/10.1088/1748-9326/8/4/044012

Wang, Y.Y., Jia, Y.F., Guan, L., Lu, C., Lei, G.C., Wen, L., and Liu, G.H. (2013b). Optimising hydrological conditions to sustain wintering waterbird populations in Poyang Lake National Natural Reserve: Implications for dam operations. Freshw. Biol., 58, 2366-2379.

Wu, H., Zeng, G., Liang, J., Chen, J., Xu, J., Dai, J., Li, X., Chen, M., Xu, P., Zhou, Y., Li, F., Hu, L., and Wan, J. (2016). Responses of bacterial community and functional marker genes of nitrogen cycling to biochar, compost and combined amendments in soil. Appl. Microbiol. Biotechnol., 100, 8583-8591. https://doi.org/10.1007/ s00253-016-7614-5

Wu, H., Zeng, G., Liang, J., Chen, J., Xu, J., Dai, J., Sang, L., Li, X., and Ye, S. (2017). Responses of landscape pattern of China's two largest freshwater lakes to early dry season after the impoundment of Three-Gorges Dam. Int. J. Appl. Earth Obs. Geoinf., 56, 36-43. https://doi.org/10.1016/j.jag.2016.11.006

Wu, H., Zeng, G., Liang, J., Guo, S., Dai, J., Lu, L., Wei, Z., Xu, P., Li, F., Yuan, Y., and He, X. (2015). Effect of early dry season induced by the Three Gorges Dam on the soil microbial biomass and bacterial community structure in the Dongting Lake wetland. Ecol. Indic., 53, 129-136. https://doi.org/10.1016/j.ecolind.2015.01.041

Wu, H., Zeng, G., Liang, J., Zhang, J., Cai, Q., Huang, L., Li, X., Zhu, H., Hu, C., and Shen, S. (2013). Changes of soil microbial biomass and bacterial community structure in Dongting Lake: Impacts of 50,000 dams of Yangtze River. Ecol. Eng., 57, 72-78. https:// doi.org/10.1016/j.ecoleng.2013.04.038

Xia, S., Liu, G., Yu, X., and Liu, Y. (2015). Importance assessment of wintering habitats for migratory waterfowl in Lake Poyang. J. Lake Sci., 27(4), 719-726. https://doi.org/10.18307/2015.0421

Xie, Y. L., Xia, D. X., Ji, L., and Huang, G. H. (2018). An inexact stochastic-fuzzy optimization model for agricultural water allocation and land resources utilization management under considering effective rainfall. Ecol. Indic., 92, 301-311, https://doi.org/10. 1016/j.ecolind.2017.09.026

Xin, X., Huang, G., An, C., Huang, C., Weger, H., Zhao, S., Zhou, Y., and Rosendahl, S. (2018). Insights into the toxicity of triclosan to green microalga Chlorococcum sp. using synchrotron-based fourier transform infrared spectromicroscopy: biophysiological analyses and roles of environmental factors. Environ. Sci. \& Technol., 52(4), 2295-2306, http:// dx.doi.org/10.1021/acs.est. 7b05533

Xu, P., Zeng, G., Huang, D., Feng, C., Hu, S., Zhao, M., Lai, C., Wei, Z., Huang, C., Xie, G., and Liu, Z. (2012). Use of iron oxide nanomaterials in wastewater treatment: A review. Sci. Total Environ., 424, 1-10. https://doi.org/10.1016/j.scitotenv.2012.02.023

Yang, C., Chen, H., Zeng, G., Yu, G., and Luo, S. (2010). Biomass accumulation and control strategies in gas biofilters. Biotechnol. Adv., 28, 531-540. https://doi.org/10.1016/j.biotechadv.2010.04.002

Yi, Y., Cheng, X., Yang, Z., Wieprecht, S., Zhang, S., Wu, Y. (2017). Evaluating the ecological influence of hydraulic projects: A review of aquatic habitat suitability models. Renew. Sust. Energ. Rev., 68 ,
748-762. https://doi.org/10.1016/j.r ser.2016.09.138

Yu, L., Li, Y. P., and Huang, G. H. (2019). Planning municipal-scale mixed energy system for stimulating renewable energy under multiple uncertainties-The City of Qingdao in Shandong Province, China. Energy, 166, 1120-1133, https://doi.org/10.1016/j.energy. 2018.10.157

Yuan, Y.J., Zeng, G.M., Liang, J., Li, X.D., Li, Z.W., Zhang, C., Huang, L., Lai, X., Lu, L.H., Wu, H.P., and Yu, X. (2014). Effects of landscape structure, habitat and human disturbance on birds: A case study in East Dongting Lake wetland. Ecol. Eng., 67, 67-75. https:// doi.org/10.1016/j.ecoleng.2014.03.012

Zeng, G., Chen, M., and Zeng, Z. (2013a). Risks of Neo- nicotinoid Pesticides. Science, 340(6139), 1403. https://doi.org/10.1126/scien ce.340.6139.1403-a

Zeng, G., Chen, M., and Zeng, Z. (2013b). Shale gas: surface water also at risk. Nature, 499, 154. https://doi.org/10.1038/499154c

Zeng, G., Wu, H., Liang, J., Guo, S., Huang, L., Xu, P., Liu, Y., Yuan, Y., He, X., and He, Y. (2015). Efficiency of biochar and compost (or composting) combined amendments for reducing $\mathrm{Cd}, \mathrm{Cu}, \mathrm{Zn}$ and $\mathrm{Pb}$ bioavailability, mobility and ecological risk in wetland soil. RSC Adv., 5, 34541-34548. https://doi.org/10.1039/C5RA04834F

Zhang, C., Yuan, Y.J., Zeng, G.M., Liang, J., Guo, S.L., Huang, L., Hua, S.S., Wu, H.P., Zhu, Y., An, H.X., and Zhang, L.H. (2016). Influence of hydrological regime and climatic factor on waterbird abundance in Dongting Lake Wetland, China: Implications for biological conservation. Ecol. Eng., 90, 473-481. https://doi.org/ 10.1016/j.ecoleng.2016.01.076

Zhang, J. L., Li, Y. P., Zeng, X. T., Huang, G. H., Li, Y., Zhu, Y., Kong, L., Xi, M., and Liu, J. (2019). Effluent trading planning and its application in water quality management: A factor-interaction perspective. Environ. Res., 168, 286-305, https://doi.org/10.1016 /j.envres.2018.09.029

Zhang,Y., Wang, Z., Ren, C., Yu, H., Dong, Z., Lu, C., and Mao, D. (2017). Changes in habitat suitability for waterbirds of the Momoge Nature Reserve of China during 1990-2014. J. Environ. Eng. Landsc., 25, 367-378. https://doi.org/10.3846/16486897.2017.1316982

Zhang, Y., Zeng, G.M., Tang, L., Huang, D.L., Jiang, X.Y., and Chen, Y.N. (2007). A hydroquinone biosensor based on immobilizing laccase to modified core-shell magnetic nanoparticles supported on carbon paste electrode. Biosens. Bioelectron., 22, 2121-2126. htt ps://doi.org/10.1016/j.bios.2006.09.030

Zhou, Y., Tang, L., Yang, G., Zeng, G., Deng, Y., Huang, B., Cai, Y., Tang, J., Wang, J., and Wu, Y. (2016a). Phosphorus-doped ordered mesoporous carbons embedded with $\mathrm{Pd} / \mathrm{Fe}$ bimetal nanoparticles for the dechlorination of 2,4-dichlorophenol. Catal. Sci. Technol., 6, 1930-1939. https://doi.org/10.1039/C5CY01514F

Zhou, Y., Tang, L., Zeng, G., Chen, J., Cai, Y., Zhang, Y., Yang, G., Liu, Y., Zhang, C., and Tang, W. (2014). Mesoporous carbon nitride based biosensor for highly sensitive and selective analysis of phenol and catechol in compost bioremediation. Biosens. Bioelectron., 61, 519-525. https://doi.org/10.1016/j.bios.2014.05.063

Zhou, Y., Tang, L., Zeng, G., Zhang, C., Zhang, Y., and Xie, X. (2016b). Current progress in biosensors for heavy metal ions based on DNAzymes/DNA molecules functionalized nanostructures: A review. Sensors Actuators B: Chem., 223, 280-294.

Zohmann, M., Pennerstorfer, J., and Nopp-Mayr, U. (2013). Modelling habitat suitability for alpine rock ptarmigan (Lagopus muta helvetica) combining object-based classification of IKONOS imagery and Habitat Suitability Index modelling. Ecol. Model., 254, 22-32. https://doi.org/10.1016/j.ecolmodel.2013.01.008

Zou, S., Liu, X., Liu, X., and Guo, C. (2000). Impacts of Three Gorges Dam Project on emergence length of beach in Dongting Lake. Resour. Environ. Yangtze Basin, 2, 254-259. 